\title{
Purification and Properties of Cyclodextrin Glycosyltransferase of an Alkalophilic Bacillus sp.
}

\author{
Nobuyuki Nakamura and Koki HorikoshI \\ Laboratory of Ecological Microbiology, The Institute of Physical \\ and Chemical Research, Wako-shi, Saitama-ken 351
}

Received November 7, 1975

\begin{abstract}
Extracellular cyclodextrin glycosyltransferase $(\alpha-1,4$-glucan 4 -glycosyltransferase, cyclizing, EC 3.2.1.19) of an alkalophilic Bacillus sp. (ATCC 21783) was purified about 74 -fold and shown to be a single, homogeneous protein by disc polyacryl amide gel electrophoresis and ultracentrifugation. The molecular weight and isoelectric point were 88,000 and $\mathrm{pH} 5.4$. The optimum $\mathrm{pH}$ for the enzyme action was $4.5 \sim 4.7$. The apparent $V_{\max }$ and $K m$ values for $\alpha-, \beta$ - and $\gamma$-cyclodextrin at the constant concentration of sucrose were 133.3, 23.4, $12.3 \mu$ moles glucose/min per $\mathrm{mg}$ protein and $5.88,0.39,0.25 \mathrm{~mm}$, respectively. The enzyme converted about $73 \%$ of starch, $65 \%$ of amylopectin, $45 \%$ of glycogen and $25 \%$ of anylopectin $\beta$-limit dextrin to cyclodextrins.
\end{abstract}

The Schardinger dextrins (cyclodextrins, CD) are homologous series of non-reducing, cyclic, D-glucose polymers ranging in size from six to twelve glycosyl ring structure and beyond. ${ }^{1,2)}$ The existence of exo- and endobranched cyclic dextrins has been also reported. ${ }^{3)}$ These dextrins are synthesized from starch and related materials by cyclodextrin glycosyltransferase (CGTase) produced from Bacillus sp. Although the properties and action on starch of the enzyme of $B$. macerans (BMA) have been extensively studied, ${ }^{4 \sim 8)}$ the investigations of those from other strains have not been reported so much. ${ }^{9 \sim 12)}$

We have isolated an alkalophilic soil bacterium which produce extracellular cyclodextrin glycosyltransferase by an alkalophilic medium containing $1 \% \mathrm{Na}_{2} \mathrm{CO}_{3}$. This paper deals with the purification procedures and some properties of the enzyme of this strain (alkalophilic Bacillus sp., ATCC 21783). The mode of action of the enzyme will be reported latter studies.

\section{MATERIALS AND METHODS}

Microorganism. An alkalophilic Bacillus sp. (AT$\mathrm{CC}$ 21783) was maintained on the II-medium agar slant ${ }^{13)}$ and stored at room temperature.
CGTase activity. The reaction mixture containing $5 \mathrm{~mm} \alpha$-cyclodextrin, $25 \mathrm{~mm}$ sucrose, $0.5 \mathrm{mg}$ of glucoamylase in $0.35 \mathrm{ml}$ of $0.2 \mathrm{M}$ acetate buffer ( $\mathrm{pH} 4.65$ ) and $10 \mu 1$ of the enzyme suitably diluted with distilled water was incubated at $40^{\circ} \mathrm{C}$ for $10 \mathrm{~min}$. The reaction was stopped by the addition of $1 \mathrm{ml}$ of 3,5dinitrosalicylic acid (DNS) solution and then heated in a boiling water bath for $5 \mathrm{~min}$. Absorbance was determined at $510 \mathrm{~nm}$ with using glucose as a standard by DNS-method as described by Summer and Somers. ${ }^{14)}$ One unit of the enzyme is defined as the amount of enzyme to liberate $1 \mu \mathrm{mole}$ of glucose per minute under the described conditions.

Dextrinizing activity. Dextrinizing activity was determined by the measurement of dextrinizing power using amylose as a substrate according to Fuwa's method $^{15)}$ with slight modification. In the standard assay, the reaction mixture containing $10 \mu \mathrm{l}$ of the enzyme suitably diluted with distilled water and $0.3 \mathrm{ml}$ of $0.2 \%$ amylose in $0.2 \mathrm{M}$ acetate buffer $(\mathrm{pH} 4.65)$ was incubated at $40^{\circ} \mathrm{C}$ for $10 \mathrm{~min}$. The reaction was stopped with $1 \mathrm{ml}$ of $0.5 \mathrm{M}$ acetic acid and $0.5 \mathrm{ml}$ of $0.02 \% \mathrm{I}_{2} / 0.2 \% \mathrm{KI}$ solution. Distilled water was added to make a volume of $10 \mathrm{ml}$, and absorbance at $700 \mathrm{~nm}$ was measured. One unit of the enzyme is defined as the amount of enzyme which produces $10 \%$ reduction in the intensity of blue colour of amyloseiodine complex per minute under the described conditions.

Other analytical methods. The formation of cyclodextrins was monitored during the purification by trichloroethylene test. The reaction mixture con- 
taining $2 \mathrm{ml}$ of $3 \%$ potato starch in $0.1 \mathrm{M}$ acetate buffer ( $\mathrm{pH} 4.65$ ), $0.5 \mathrm{ml}$ of trichloroethylene and $0.5 \mathrm{ml}$ of the enzyme was incubated for $30 \mathrm{~min}$ at $40^{\circ} \mathrm{C}$. White precipitate was formed by vigorous stirring when cyclodextrins were formed. The yield of cyclodextrins was determined by the glucoamylase method described by Kobayashi et $a l^{16,17)}$ Protein was estimated by the method of Warburg and Christian. ${ }^{13}$ ) Disc polyacrylamide gel electrophoresis was carried out by the method of Davis. ${ }^{19)} \quad$ Ampholine isoelectrofocusing was done by the method of Vesterberg and Svesson. ${ }^{20)}$ Molecular weight was estimated by SDS-disc polyacrylamide gel electrophoresis described by Neville. ${ }^{21}$ Total carbohydrate was determined by anthrone$\mathrm{H}_{2} \mathrm{SO}_{4}$ method described by Morris. ${ }^{22}$ )

Materials. The amylase of B. macerans (IFO 3490) was prepared by the method of Kitahata et al. ${ }^{93}$ Amylose and glucoamylase (Pure grade, $22.3 \mathrm{U} / \mathrm{mg}$, EC 3.2.1.3) of Rhizopus niveus were purchased from Seikagaku Kogyo Co. Schardinger $\alpha$-dextrin was obtained from Sigma Chemicals Co., U.S.A., and $\gamma$ dextrin was kindly donated by Dr. T. Kuge (Kyoto Pref. Univ.). Schardinger $\beta$-dextrin, maltotriose, corn starch and corn steep liquor were supplied by Nihon Shokuhin Kako Co. Amylopectin $\beta$ - and $\alpha, \beta$-limit dextrin were generous gifts of Dr. K. Watanabe of our laboratory. Ampholine carrier ampholite $(\mathrm{pH}$ 3.5 10) was from L.K.B.-Producter, Sweden. Fícoll was from Pharmacia Fine Chemicals Co., Sweden.

\section{RESULTS}

\section{Purification of the enzyme}

Unless stated otherwise, all operations were carried out at room temperature.

1. Preparation of the crude CGTase. The organism was grown aerobically for 2 days at $37^{\circ} \mathrm{C}$ in the medium consisting (g/liter) $10 \mathrm{~g}$ of soluble starch, $50 \mathrm{~g}$ of corn steep liquor, $1 \mathrm{~g}$ of $\mathrm{K}_{2} \mathrm{HPO}_{4}, 0.2 \mathrm{~g}$ of $\mathrm{MgSO}_{4} \cdot 7 \mathrm{H}_{2} \mathrm{O}$ and separately sterilized $10 \mathrm{~g}$ of $\mathrm{Na}_{2} \mathrm{CO}_{3}$. The cells were removed by centrifugation at $0^{\circ} \mathrm{C}$. To 1 volume of the supernatant, 3 volumes of cold acetone $\left(-20^{\circ} \mathrm{C}\right)$ were added, and the mixture was stored in a cold room for overnight. The precipitate formed was collected by centrifugation and resolved with tap water. This solution was dialyzed against running tap water for 2 days.

2. Starch adsorption. Corn starch $(3 \%)$ and ammonium sulfate $(20 \%)$ were added to the dialyzate and stirred for $60 \mathrm{~min}$ at $0 \sim$ $4^{\circ} \mathrm{C}$. The corn starch which adsorbed the enzyme was collected by filtration and washed with $10 \mathrm{~mm}$ phosphate buffer ( $\mathrm{pH} 7.0$ ) containing $20 \%(\mathrm{w} / \mathrm{v})$ of ammonium sulfate and $1 \mathrm{M} \mathrm{NaCl}$. The enzyme was eluted from corn starch with $10 \mathrm{~mm}$ of the same buffer containing $3 \mathrm{M} \mathrm{NaCl}$ and $0.1 \mathrm{M}$ maltose. The effuluent was dialyzed for 2 days against running tap water and concentrated by polyethylene glycol (PEG) 6000.

3. Biogel $p-100$ gel filtration. The concentrate was passed through a Biogel p-100 column $(2.6 \times 100 \mathrm{~cm})$ which was equilibrated with $10 \mathrm{~mm}$ glycine- $\mathrm{NaOH}-\mathrm{NaCl}$ buffer $(\mathrm{pH}$ 8.5 ) containing $0.1 \mathrm{M} \mathrm{NaCl}$. The active fractions were collected and concentrated by PEG 6000. The concentrate was dialyzed against $10 \mathrm{~mm}$ glycine- $\mathrm{NaOH}-\mathrm{NaCl}$ buffer ( $\mathrm{pH} 8.5$ ).

4. DEAE-cellulose chromatography. The dialyzate was loaded onto a DEAE-cellulose column $(1.5 \times 45 \mathrm{~cm})$ equilibrated with the same buffer described above. After the column was washed with the same buffer, the enzyme was eluted with a linear gradient of $\mathrm{NaCl}$. A linear gradient of $\mathrm{NaCl}$ was obtained by using a Ultrograd (LKB-producter AB, Sweden). Active fractions were collected and concentrated by PEG 6000 .

5. Sephadex $G-100$ gel filtration. The concentrate was passed through a Sephadex G-100 column $(1.5 \times 100 \mathrm{~cm})$ which equilibrated with the same buffer containing $0.1 \mathrm{M}$ $\mathrm{NaCl}$. A typical elution pattern is shown in Fig. 1. Active fractions were collected and concentrated by Ficoll 400. This enzyme was used for the following experiments. The results are summarized in Table $I$.

\section{Homogeneity of the enzyme}

The purified enzyme gave a single band of protein by disc gel electrophoresis (Fig. 2) and showed a symmetrical peak by ultracentrifugation $\left(s_{20, \mathrm{w}} ; 4.6\right)$ and isoelectrofocusing (pI; 5.4). In $10 \mathrm{~mm}$ phosphate buffer ( $\mathrm{pH}$ 8.0 ), the enzyme showed a typical absorption spectrum of protein. The ratio of absorption at $280 \mathrm{~nm}$ to $260 \mathrm{~nm}$ was about 1.9. This value indicated the absence of nucleic acid. 
Table I. Purification Summary of the CGTase of Alkalophilic Bacillus sp.

\begin{tabular}{lccccc}
\hline \multicolumn{1}{c}{ Steps } & $\begin{array}{c}\text { Volume } \\
(\mathrm{ml})\end{array}$ & $\begin{array}{c}\text { Activity } \\
\text { (Units) }\end{array}$ & $\begin{array}{c}\text { Protein } \\
(\mathrm{mg})\end{array}$ & $\begin{array}{c}\text { Sp. activity } \\
(\text { Units/mg) }\end{array}$ & $\begin{array}{c}\text { Recovery } \\
(\%)\end{array}$ \\
\hline Culture fluid & 300 & 10,440 & 9550 & 1.09 & 100 \\
Starch adsorption & 540 & 10,750 & 250 & 43.0 & 103 \\
Biogel p-100 & 26.5 & 9,290 & 140 & 66.4 & 89 \\
DEAE-cellulose & 190 & 4,810 & 64 & 75.2 & 46 \\
Sephadex G-100 & 30 & 3,800 & 47 & 81.1 & 35 \\
\hline
\end{tabular}

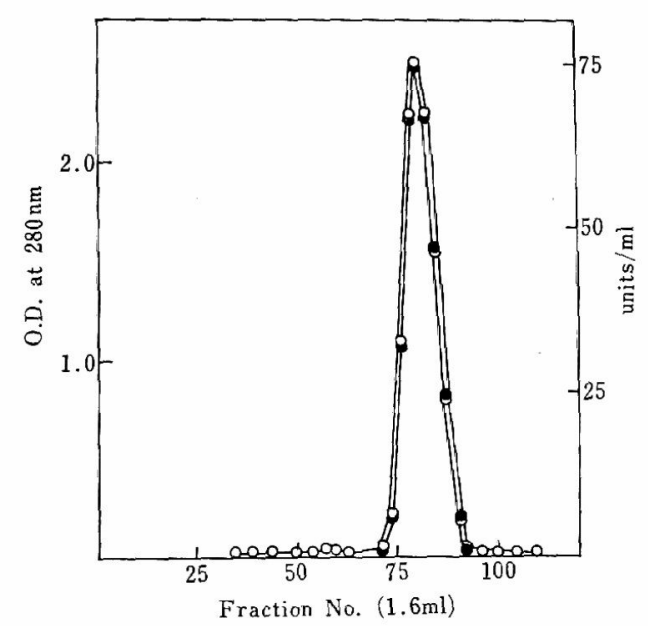

FIG. 1. Gel Filtration of Cyclodextrin Glycosyltransferase of Alkalophilic Bacillus sp. on a Sephadex G-100 Column.

The experimental details are described in the text. Symbols express; the enzyme activity ( $\bullet$ ), absorbance at $280 \mathrm{~nm}(\mathrm{O}-\mathrm{O})$.

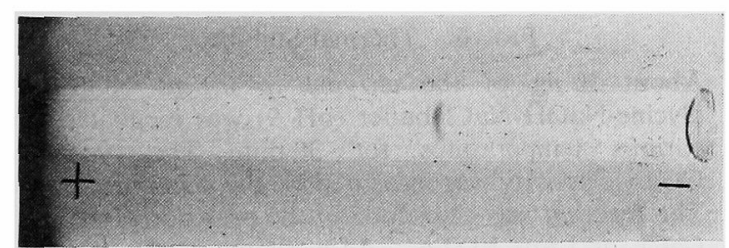

FIg. 2. Disc Gel Electrophoresis Pattern of the Purified Enzyme.

The purified CGTase containing about $20 \mu \mathrm{g}$ of protein was subjected to a column of the electrophoresis at $\mathrm{pH} 9.4$.

The molecular weight was calculated as 88,000 by SDS-disc polyacrylamide gel electrophoresis.

\section{Effect of $\mathrm{pH}$ on activity}

Because of inability to determine at all of $\mathrm{pH}$ ranges tested by the standard assay, the

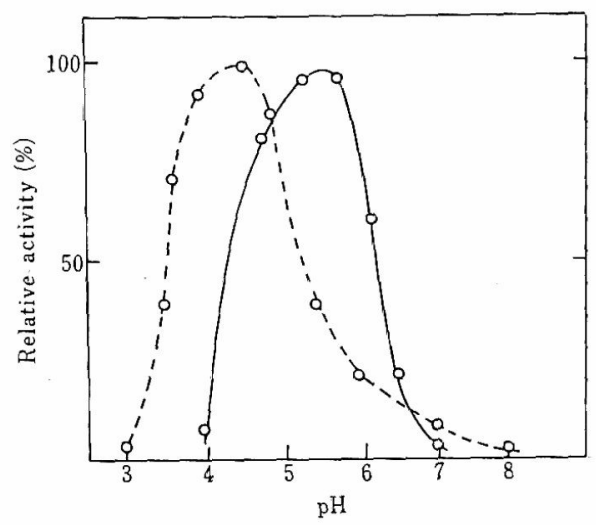

FIG. 3. Effect of $\mathrm{pH}$ on Activity.

The $\mathrm{pH}$ vs CGTase activity was measured as described in the text. The $\mathrm{pH}$ was adjusted with the following buffer systems; acetate buffer ( $\mathrm{pH} 3 \sim 5$ ), phosphate buffer $(\mathrm{pH} 5.5 \sim 8)$. Solid line expresses $\mathrm{pH}$ vs activity curve of BMA and dotted line expresses alkalophilic Bacillus sp. enzyme

CGTase activity was measured by following method. The reaction mixture containing $5 \mathrm{~mm} \alpha$-cyclodextrin, $25 \mathrm{~mm}$ sucrose in $0.3 \mathrm{ml}$ of $50 \mathrm{~mm}$ various buffer solutions and $10 \mu \mathrm{l}$ of the enzyme was incubated at $40^{\circ} \mathrm{C}$ for $10 \mathrm{~min}$. The reaction was terminated by heating in a boiling water bath for $10 \mathrm{~min}$. The reaction mixture was incubated with $0.5 \mathrm{mg}$ of glucoamylase in $0.5 \mathrm{ml}$ of $0.5 \mathrm{M}$ acetate buffer $(\mathrm{pH}$ 5.0) at $45^{\circ} \mathrm{C}$ for $2 \mathrm{hr}$. Glucose thus liberated was determined as described above. As a reference, BMA was tested under the same conditions. As shown in Fig. 3, the optimum $\mathrm{pH}$ for the enzyme action of the enzyme was $4.5 \sim 4.7$.

\section{Effect of $\mathrm{pH}$ on stability}

The enzyme was dissolved in various buffer solutions and heated at $60^{\circ} \mathrm{C}$ for $30 \mathrm{~min}$. After the enzyme was brought to $\mathrm{pH} 4.65$, 
the residual activity was measured under the standard assay method. The enzyme was stable at the range of $\mathrm{pH} 6 \sim 10$ under the tested conditions (Fig. 4).

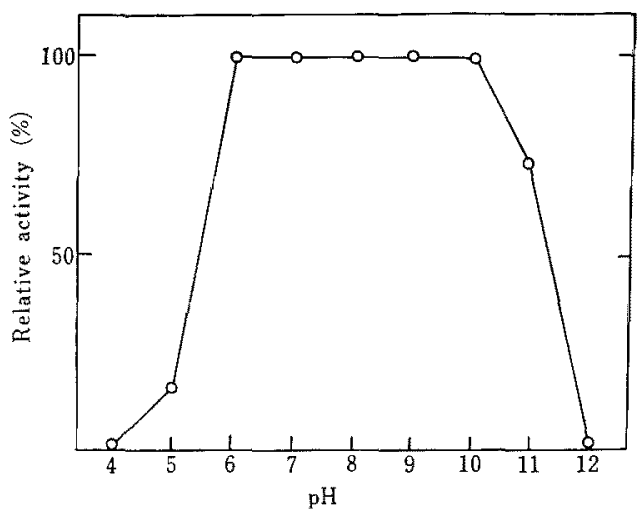

FIG, 4. Effect of $\mathrm{pH}$ on Stability.

About $50 \mu \mathrm{g}$ of the enzyme in $0.1 \mathrm{ml}$ of $0.05 \mathrm{M}$ various buffer solutions was incubated at $60^{\circ} \mathrm{C}$. After $30 \mathrm{~min}$, the enzyme solution was brought to $\mathrm{pH} 4.65$ by the addition of $0.5 \mathrm{ml}$ of $0.5 \mathrm{M}$ acetate buffer $(\mathrm{pH} 4.65)$, and the residual CGTase activity was measured by the standard assay. The $\mathrm{pH}$ was adjusted with the following buffer systems; acetate (pH 4 5), phosphate ( $\mathrm{pH} 6 \sim 8$ ), glycine- $\mathrm{NaOH}-$ $\mathrm{NaCl}(\mathrm{pH} 9 \sim 12)$.

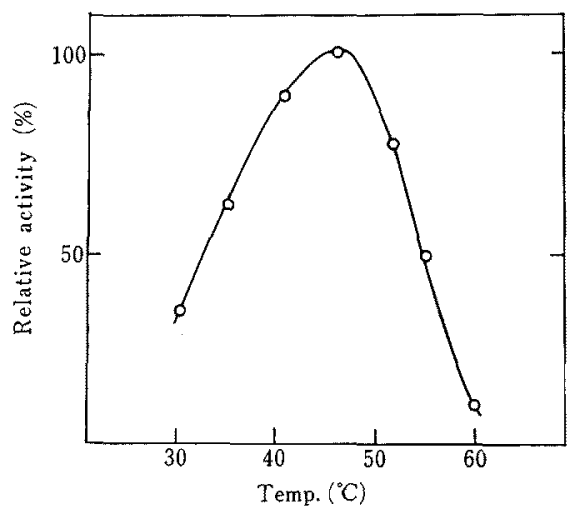

FIG. 5. Effect of Temperature on Activity

The CGTase activity was measured at various temperatures as follows. The reaction mixture containing $5 \mathrm{~mm} \alpha$-cyclodextrin, $25 \mathrm{~mm}$ sucrose in $0.3 \mathrm{ml}$ of $0.2 \mathrm{M}$ acetate buffer $(\mathrm{pH} 4.65$ ) and $10 \mu \mathrm{l}$ of the enzyme was incubated at various temperatures for $10 \mathrm{~min}$. The reaction was stopped by heating in a boiling water bath for $10 \mathrm{~min}$. Then, the reaction mixture was incubated with $0.5 \mathrm{mg}(50 \mu \mathrm{l})$ of glucoamylase solution at $45^{\circ} \mathrm{C}$ for $5 \mathrm{hr}$. Glucose thus formed was determined as described above.

\section{Effects of temperature on activity}

The enzyme activity was measured at $\mathrm{pH}$ 4.65 and various temperatures. As shown in Fig. 5, the optimum temperature for the enzyme action was about $45^{\circ} \mathrm{C}$.

\section{Thermal stability}

The enzyme dissolved in $0.1 \mathrm{M}$ glycine$\mathrm{NaOH}-\mathrm{NaCl}$ buffer $(\mathrm{pH} 9.0)$ was treated at various temperatures for $30 \mathrm{~min}$. And the residual activity was measured at $\mathrm{pH} 4.65$. The reaction was also done in the presence of $10 \mathrm{mM} \mathrm{CaCl}_{2}$ or $1 \mathrm{~mm}$ EDTA. As a reference, the enzyme also treated by the same method in a $0.1 \mathrm{M}$ acetate buffer ( $\mathrm{pH} 4.65$ ). As shown in Fig. 6, although the enzyme was very un-

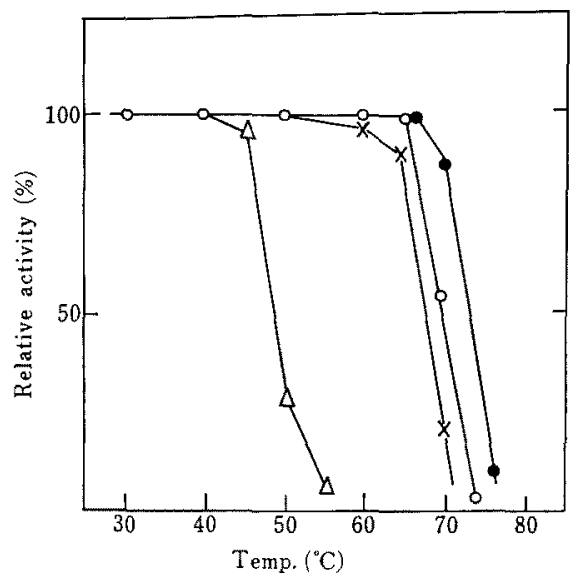

FIG. 6. Thermal Stability.

About $50 \mu \mathrm{g}$ of the enzyme in $0.1 \mathrm{ml}$ of $0.1 \mathrm{M}$ glycine- $\mathrm{NaOH}-\mathrm{NaCl}$ buffer $(\mathrm{pH}$ 9) was incubated at various temperatures for $30 \mathrm{~min}$. The residual CGTase activity was measured by the standard assay. The reaction was also done in the presence of $10 \mathrm{~mm}$ $\mathrm{CaCl}_{2}$ or $1 \mathrm{mM}$ EDTA. As a reference, the enzyme also treated in $0.1 \mathrm{M}$ acetate buffer ( $\mathrm{pH} 4.65)$. Symbols express that $(-0)+\mathrm{CaCl}_{2},(x-x)+$ EDTA, $(\mathrm{O}-\mathrm{O})$ control, and $(\triangle-\triangle)$ treated at $\mathrm{pH} 4.65$.

stable when the incubation was done at acidic condition, the enzyme stable up to $65^{\circ} \mathrm{C}$ and slightly stabilized by $\mathrm{Ca}^{2+}$, and the addition of EDTA decreased its thermal stability.

\section{Effect of co-substrates on activity}

The effect of various cosubstrates on the dextrinizing activity was compared with that 
of BMA. Each of carbohydrates which was added to $0.3 \mathrm{ml}$ of $0.2 \%$ amylose in $0.2 \mathrm{M}$ acetate buffer ( $\mathrm{pH} 4.65)$ was incubated with $10 \mu 1$ of the enzyme at $40^{\circ} \mathrm{C}$ for $10 \mathrm{~min}$. The decrease of blue colour of amylose-iodine complex was determined by the method described above.

Table II. Effect of Co-substrates on Dextrinizing Activity

\begin{tabular}{lccc}
\hline Compounds & $\begin{array}{c}\text { Conctn. } \\
(\%)\end{array}$ & $\begin{array}{c}\text { Relative activity } \% \\
\text { The } \\
\text { CGTase }\end{array}$ & BMA \\
\hline Control & - & 100 & 100 \\
Glucose & 0.05 & 270 & 370 \\
Maltose & $\prime \prime$ & 330 & 550 \\
Maltotriose & $\prime \prime$ & 250 & 440 \\
Sucrose & $" \prime$ & 170 & 120 \\
Fructose & $\prime \prime$ & 140 & 97 \\
Lactose & $\prime \prime$ & 150 & 95 \\
Sorbitol & $\prime \prime$ & 140 & 95 \\
Schardinger & 0.3 & 100 & 65 \\
$\quad \beta$-dextrin & & & \\
\hline
\end{tabular}

As shown in Table II, the rate of the enzyme action was accelerated by the addition of various saccharides. Starch hydrolyzates such as glucose, maltose and maltotriose were less effective, but other carbohydrates were more effective than that observed by BMA. The enzyme was not inhibited by $\beta$-cyclodextrin at the tested concentration.

Determination of $V_{\max }$ and $K m$ values of glycosyl residues transfer action

The glycosyl residue transfer action to sucrose was examined by double reciprocal plot (Fig. 7). The apparent maximum velocity $\left(V_{\max }\right)$ and Michaelis constant $(\mathrm{Km})$ values for $\alpha-, \beta$ - and $\gamma$-cyclodextrin at a constant concentration of sucrose were $133.3,23.4,12.3$ $\mu$ moles glucose/min per $\mathrm{mg}$ of protein and $5.88,0.39,0.25 \mathrm{~mm}$, respectively.

Formation of cyclodextrins from starch and related materials

Formation of cyclodextrins from various substrates was investigated. As shown in Fig. 8, the enzyme converted $73 \%$ of potato starch, $65 \%$ of amylopectin, $45 \%$ of oyster

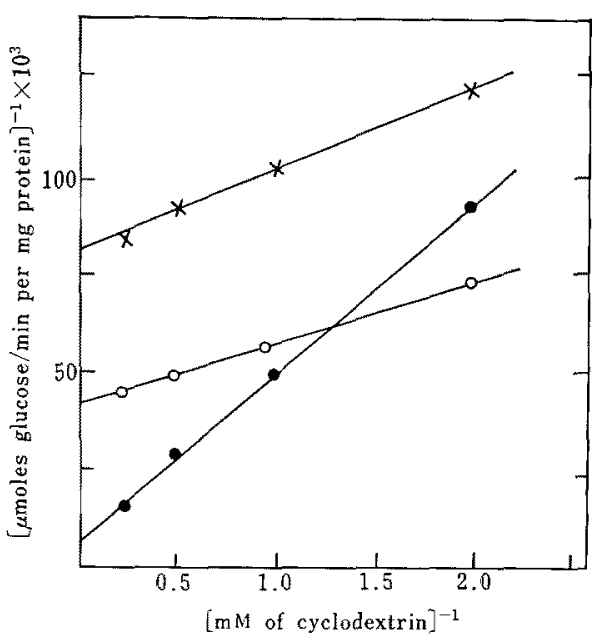

FiG. 7. Double Reciprical Plot with $\alpha, \beta$ - and $\gamma$ Cyclodextrin as Variable Substrate.

The reaction mixture containing $25 \mathrm{~mm}$ sucrose, $0.5 \mathrm{mg}$ glucoamylase, $0 \sim 5 \mathrm{~mm}$ cyclodextrin in $0.35 \mathrm{ml}$ of $0.2 \mathrm{M}$ acetate buffer ( $\mathrm{pH} 4.65$ ) and $10 \mu \mathrm{l}$ of the enzyme was incubated at $40^{\circ} \mathrm{C}$ for $10 \mathrm{~min}$. The reaction was stopped by the addition of $1 \mathrm{ml}$ of 3,5-DNS solution, and the mixture was heated in a boiling water bath for $5 \mathrm{~min}$. After the mixture was made up to $5 \mathrm{ml}$ with distilled water, the absorbance was measured at $510 \mathrm{~nm}$ with using glucose as a standard. Symbols express that (-); $\alpha$ cyclodextrin, $(O-0) ; \beta$-cyclodextrin, $(x-x) ; \gamma$ cyclodextrin.

glycogen and $25 \%$ of amylopectin $\beta$-limit dextrin at $1 \%(\mathrm{w} / \mathrm{v})$ of substrates concentration.

\section{DISCUSSION}

The CGTase of an alkalophilic Bacillus sp. was purified about 74-fold by corn starch adsorption, Biogel p-100 gel filtration and DEAEcellulose chromatography followed by Sephadex G-100 gel filtration.

The purified enzyme was homogeneous on ultracentrifugation, disc polyacrylamide gel electrophoresis and ampholine isoelectrofocusing. The enzyme thus obtained was very thermostable at alkaline region and having a optimum $\mathrm{pH}$ range for the enzyme action at 4.5 4.7. As a reference, BMA was compared with this enzyme. The enzyme was different from BMA in accordance with the isoelectric point (BMA, pI; 4.6), optimum $\mathrm{pH}$ for the 


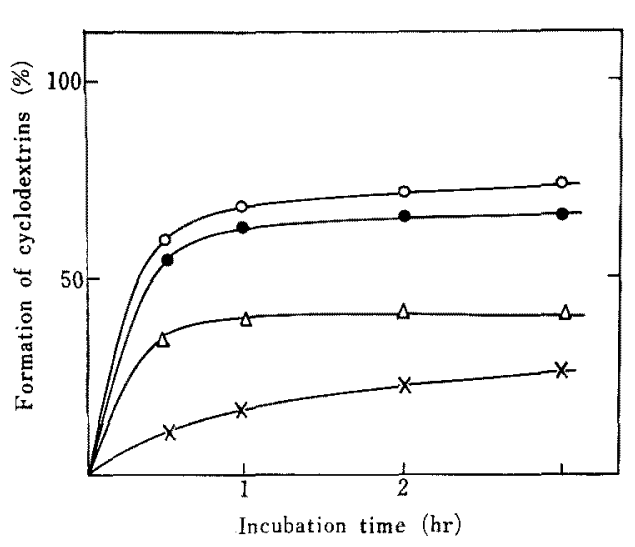

FIG. 8, Formation of Cyclodextrins from Starch and Related Materials.

The reaction mixture containing $1 \%(\mathrm{w} / \mathrm{v})$ of various substrates in $2 \mathrm{ml}$ of $0.2 \mathrm{M}$ acetate buffer ( $\mathrm{pH} 4.65$ ) was incubated with $15 \mu \mathrm{g}(10 \mu \mathrm{l})$ of the enzyme at $45^{\circ} \mathrm{C}$ for various periods. The aliquot $(0.3 \mathrm{ml})$ was heated in a boiling water bath for 10 min to terminate the reaction and then re-incubated with $0.25 \mathrm{mg}$ of glucoamylase at $40^{\circ} \mathrm{C}$ for $20 \mathrm{hr}$ to hydrolyze saccharides which were not converted to cyclodextrins. The yield of cyclodextrins was calculated from the difference of total reducing sugar before and after the reaction of the CGTase. Symbols express that $(\mathrm{O}-\mathrm{O})$ potato starch, (-) potato amylopectin, $(\triangle-\triangle)$ oyster glycogen and $(x-x)$ potato amylopectin $\beta$-limit dextrin.

enzyme action and the effect of co-substrates on the dextrinizing activity. The rate of dextrinizing action of the purified enzyme was less accelerated by starch hydrolyzates such as glucose, maltose and maltotriose. In addition, the enzyme was not inhibited by $\beta$-cyclodextrin by which BMA was inhibited. The apparent $V_{\max }$ and $K m$ values determined for $\alpha$-cyclodextrin were larger than those for $\beta$ - or $\gamma$-cyclodextrin. This result shows that $\alpha$ cyclodextrin is easily hydrolyzed and transfered the glycosyl residue to some acceptors, but the formation of the enzyme- $\alpha$-cyclodextrin complex is slower than those of other cyclodextrins. The enzyme converted starch and related materials to cyclodextrins with somewhat high yields than those so far reported by $\mathrm{BMA}^{1)}$ or other enzymes. ${ }^{11,12)}$ This fact suggests that the branching points of amylopectin will be bypassed or incorporated to cyclodextrins molecule.

In this work, although we failed to purify another CGTase(s) of this bacterium, at least, two CGTases might be containing in the crude enzyme. The enzyme(s) having $\mathrm{pH}$ optimum for the enzyme action in alkaline region was more unstable than the purified enzyme, especially, at the conditions of acidic and alkaline $\mathrm{pH}$. The alkaline CGTase(s) in the crude enzyme was easily inactivated by the heat treatment $\left(\mathrm{pH} 10.5,60^{\circ} \mathrm{C}, 5 \mathrm{~min}\right)$, though the CGTase having $\mathrm{pH}$-optimum at $4.5 \sim 4.7$ was remained almost all of its activity. Purification of these alkaline CGTase(s) is now studying.

As the results, we wish to conclude that the purified CGTase of alkalophilic Bacillus sp. (ATCC 21783) is different from other CGTases, especially in $\mathrm{pH}$-optimum for the enzyme action, thermal stability and yields of cyclodextrins from various substrates.

Acknowledgements. The authors indebted to Drs. T. Kuge and $\mathrm{K}$. Watanabe for the gifts of Schardinger $\gamma$-dextrin, amylopectin $\beta$ and $\alpha, \beta$-limit dextrin.

\section{REFERENCES}

1) D. French, Advan. Carbohydrate Chem., 12, 189 (1957).

2) A. O. Pulley and D. French, Biochem. Biophys. Res. Commun., 5, 11 (1961).

3) D. French, A. O. Pulley, J. A. Effenberger, M. A. Rougvie and M. Abdullah, Arch. Biochem. Biophys., 111, 153 (1965).

4) J. A. Depinto and L. L. Campbell, Biochem., 7 , 114 (1968).

5) J. A. Depinto and L. L. Campbell, Arch. Biochem. Biophys., 125, 253 (1968).

6) A. G. Lane and S. J. Pirt, J. Appl. Chem. Biotechnol., 21, 330 (1971).

7) A. G. Lane and S. J. Pirt, ibid, 38, 309 (1973).

8) S. Kobayashi, K. Kainuma and S. Suzuki, Proceedings of the Symposium on Amylase, 18, 21 (1973).

9) S. Kitahata, N. Tsuyama and S. Okada, Agr. Biol. Chem., 38, 387 (1974).

10) S. Kitahata, N. Tsuyama and S. Okada, ibid., 38, 2413 (1974).

11) S. Okada and S. Kitahata, Proceedings of the Symposium on Amylase, 18, 21 (1973).

12) M. Shiosaka and H. Fumiya, Proceedings of the Symposium on Amylase, 18, 43 (1973).

13) K. Horikoshi, Agr. Biol. Chem., 35, 1783 (1971).

14) J. R. Summer and G. E. Somers, "Laboratory Experiments in Biological Chemistry," Academic 
Press, New York, 1944, p. 3435.

15) H. Fuwa, J. Biochem. (Tokyo), 41, 583 (1954).

16) S. Kobayashi, K. Kainuma and S. Suzuki, Denpun Kagaku, 21, 131 (1974).

17) S. Kobayashi, K. Kainuma and S. Suzuki, ibid., 22, 6 (1975).

18) O. Warburg and W. Christian, Biochem. Z., 310, 384 (1942).
19) B. J. Davis, Ann. New Acad. Sci., 121, 404 (1964).

20) O. Vesterberg and H. Svensson, Acta Chim. Scand, 20, 820 (1966).

21) D. M. Neville, Jr., J. Biol. Chem., 246, 6328 (1971).

22) D. L. Morris, Science, 107, 254 (1948). 